\title{
Review
}

\section{The politics of responsibility}

\author{
Chad Lavin \\ University of Illinois Press, Urbana and Chicago, 2008, xviii + 164pp., \$40.00, \\ ISBN-13: 978-0252032974
}

Contemporary Political Theory (2012) 11, e1-e4. doi:10.1057/cpt.2011.3

Chad Lavin rethinks political responsibility beyond the familiar 'blame model' (p. xiv) by encouraging liberal individualist 'tendencies' (p. xviii) to realize that their allegedly autonomous subject is actually caught up in a structural 'web of ... relations' (p. 101). As if answering Blanchot's question 'What is this me that I am' (cited by Derrida, 1995, p. 276), Lavin delivers a porous agent: I am constrained by structures, but nevertheless enabled to resist the powers that shape me. He presents individual and collective subjects as the 'consolidation of political forces in unified beings' (p. 25), or 'sites of agency' (p. 36). Part One develops a theory of the subject - 'agency ... is ripped from the grip of liberal individualism and inserted into a postliberal theory of the subject as rooted in a set of conditions that both constrain and enable' (p. 32) - which Lavin illustrates in Part Two.

Chapter One presents liberal responsibility-as-blame as 'retrospective thinking' based on a 'dubious model of individual will' (p. 13). Noting our ability to be 'responsive' (p. 17), Lavin approaches responsibility as a feature of 'established social relations' (p. 15), as opposed to contractual obligations. In Chapters Two and Three, respectively, Lavin discusses Marx's line that 'men make their own history ... under the given and inherited circumstances with which they are directly confronted' (p. 32) and Butler's 'The one who acts ... acts precisely to the extent that he or she is constituted as an actor' (p. 45). He feels that both authors negotiate between overly individualistic and overly structural extremes.

Chapter Two argues that Marx's Eighteenth Brumaire relies on figurative language because Marx could not adequately come to terms with how subjects such as classes, are constructed. For example, when discussing how the peasantry found a 'hero' in Louis Bonaparte, Lavin's Marx uses figurative language to indicate the way in which particular individuals become consolidation points for material forces. The 'irony' of the mediocre Bonaparte playing the role of hero illustrates, for Lavin, a 'playful' narrative in which subjects are

(C) 2012 Macmillan Publishers Ltd. 1470-8914 Contemporary Political Theory Vol. 11, 3, e1-e4 www.palgrave-journals.com/cpt/ 
'metonyms' (p. 28), a shorthand used rather loosely throughout this book to signify parts standing in for wholes. For Lavin 'Marx demonstrates how all subjects are produced by consciously or unconsciously consolidating a panoply of inputs into a coherent and autonomous space' (p. 26). He thinks that Marx anticipates Butler's claim that 'subjects are produced through the repeated performance of social conventions' (p. 32), making us 'conditioned and politically determined sites of agency instead of autonomous beings freely choosing actions' (p. 36).

Chapter Three develops this subject that is both shaped by outside forces and capable of acting on its own (p. 44). Grafting Butler's words to his own, Lavin writes, 'Subjectivity always arises from within a structured set of social and political relations, and agency - "the assumption of a purpose unintended by power" (Butler (1997, p. 15), also quoted at p. 138) - is response to the very conditions that produce events and agents' (p. 45). Note that for Lavin, 'agency ... is response' to structural conditions (power). Both Marx's (p. 24) and Butler's 'response', says Lavin, place agency on the side of what is enabled and power on the side of structures that constrain. Subjects, 'dependent' upon and 'vulnerable' to power, nevertheless retain a capacity for agency, which enables us/them to fight the power by assuming responsibility, even when not to blame. In Part Two, Lavin tracks enabled agents and constraining structures at global, local and personal levels, examining Hardt and Negri's 'multitude', community responses to police brutality and questions of social reproduction. For this last, Lavin advocates a 'more responsive program' that would include 'provision of universal health care, living wages, education, daycare, birth control and less formal modes of social support' (pp. 118-119). At all levels, he aims to 'expand and disperse responsibility' so that people become more accountable for more injustice than the blame model affords.

Lavin's innovative work reads best as a collection of citational grafts that he gathers under the overarching graft of 'post' and 'liberal'. His theory of subjects-as-sites-of-agency transforms the logical contradiction between the 'voluntarist subject' and 'reducing subjects to expressions of structures' (p. 87) into an continuum. In the no longer excluded middle between agency and structure, he locates 'the porousness of the agent and the inherently metonymic process that is the identification of subjects' (p. 87). He leaves us 'recognizing interpellated actors capable of responding to situations by virtue of their interpellations' (p. 135).

But Lavin's shorthand signifier, 'metonymy', disguises the price he pays for his middling position between agency and structure. His easy-going use of this term to describe swapping parts for wholes (in ways that others might call 'synecdoche'), would free us from the slippage, skid, unavoidable ambiguity of our associative metonymic chains. All parts appear generalizable. 
For example, Lavin's Marx cannot distinguish the rural surplus population from the conservative peasantry, when these 'peasant' parts supposedly find representation in Bonaparte. Lavin's broad strokes (and possible mistropes) erase those outside the locus of recognizable part-whole relations, who struggle in vain to 'self-synecdochise' (Spivak, 2005, p. 481), or decide for themselves, which forms of political representation to pursue at which historical moment.

Lavin even resolves what Butler terms the 'irresolvable ambiguity' in 'agency' by cutting out the haunting part that assumes purposes intended by power (1997, p. 15). When he quotes Butler defining agency as 'the assumption of a purpose unintended by power', he excises this qualifying addendum: '... to which it nevertheless belongs' (Butler, 1997, p. 15). She continues, 'that agency is implicated in subordination is not a sign of a fatal self-contradiction ... But neither does it restore a pristine notion of a subject ... whose agency is always and only opposed to power' (1997, p. 17). Not being able to distinguish 'between the power that forms the subject and the subject's "own" power' - the part that is our history (structure) and the part we are making up (agency) installs, for Butler, a both-and relation that admits the 'logical excrescence' (1997, p. 15, 17) exiled from Lavin's more orderly continuum. Her haunting question, 'how to take an oppositional relation to power that is, admittedly, implicated in the very power one opposes' (1997, p. 17), reiterates a marked 'ambivalence at the heart of agency' (1997, p.18). In other words, best intentions dominate others, lavish generosities exploit workers, noble inclusions exclude fellow travelers.

Lavin allows for exciting calculations and new forms of accountability, but at the cost of eliminating unaccountable, unassumable, undecidable elements of responsibility. His alluring agenda for justice (promise without pain and dynamism) protects 'us' from a full interrogation and conceives others as parts of wholes we recognize. In this sense, his substitution of a subject-centered politics of shared responsibility for the old subject-centered politics of blame offers new alibis. Beyond asking 'what is this me that I am', Blanchot would advise Lavin to 'seize hold of himself and not let go, no longer as an "I?" ' But as a "Who?", the unknown and sliding being of an indefinite "who?", (Derrida, 1995, p. 276).

Sliding from the 'just right' midpoint of agency frio and structure caliente through the 'logical excrescence' oozing through and around any Western binarism would land Lavin in liberal off-limits. Here, instead of refusing to invert, displace or even dialecticize the structure-agent relation, he could study how 'responsibility carries within it ... an essential excessiveness' (Derrida, 1995, p. 272). He could continue teaching fellow theorists how to avoid paralysis when faced with the ambiguity of agency, but without wishing, figuring away the ambiguity. 


\section{References}

Butler, J. (1997) The Psychic Life of Power. Stanford, CA: Stanford University Press.

Derrida, J. (1995) Points ... Interviews, 1974-1994, ed. E. Weber and trans. P. Kamuf. Stanford, CA: Stanford University Press.

Spivak, G.C. (2005) Scattered speculations on the subaltern and the popular. Postcolonial Studies 8(4): $475-486$.

William Corlett

Bates College, Lewiston ME, USA

e4 (C) 2012 Macmillan Publishers Ltd. 1470-8914 Contemporary Political Theory Vol. 11, 3, e1-e4 